Article

\title{
Enzyme-Assisted Aqueous Extraction of Cobia Liver Oil and Protein Hydrolysates with Antioxidant Activity
}

\author{
Yu-Hsiang Wang ${ }^{1, \dagger}$, Chia-Hung Kuo ${ }^{1, *+\dagger}{ }^{\oplus}$, Chien-Liang Lee ${ }^{2}$, Wen-Cheng Kuo ${ }^{3}$, \\ Mei-Ling Tsai ${ }^{1, *}$ and Pei-Pei Sun ${ }^{1, *}$ \\ 1 Department of Seafood Science, National Kaohsiung University of Science and Technology, \\ Kaohsiung 811, Taiwan; ys538741@live.com \\ 2 Department of Chemical and Materials Engineering, National Kaohsiung University of Science and \\ Technology, Kaohsiung 807, Taiwan; cl_lee@nkust.edu.tw \\ 3 Department of Mechatronics Engineering, National Kaohsiung University of Science and Technology, \\ Kaohsiung 811, Taiwan; rkuo@nkust.edu.tw \\ * Correspondence: kuoch@nkust.edu.tw (C.-H.K.); mltsai@nkust.edu.tw (M.-L.T.); \\ ppsun@nkust.edu.tw (P.-P.S.); Tel.: +886-7-361-7141 (ext. 23464) (C.-H.K.); (ext. 23601) (M.-L.T.); \\ (ext. 23617) (P.-P.S.) \\ + These authors contributed equally to this work.
}

Received: 22 October 2020; Accepted: 11 November 2020; Published: 14 November 2020

\begin{abstract}
Cobia, Rachycentron canadum, is a medium-size marine fish with emerging global potential for offshore aquaculture. The processing waste, cobia liver, is a raw material rich in polyunsaturated fatty acid oils. In this study, an environmentally friendly green process, aqueous extraction (AE), was used to extract the cobia liver oil. The effect of cooking time and substrate water ratio on the oil extractability was investigated herein. The cooking time of $15 \mathrm{~min}$, and substrate water ratio of 1:2 obtained the highest extraction efficiency. However, the oil extractability was only $18.8 \%$. Thus, enzyme-assisted aqueous extraction (EAAE) was used to increase oil extractability and recovery of protein hydrolysates. The commercial proteases-including alcalase, papain, trypsin, and pepsin-were employed in pretreated cobia liver in order to increase oil release during AE. The EAAE results showed that maximum oil extractability was $38 \%$ by papain pretreatment. EAAE greatly improved the extraction efficiency; the oil extractability was double than that of AE (18.8\%). The fatty acid profiles revealed that $\omega-3$ polyunsaturated fatty acid contents of extracted oil obtained from AE and EAAE were $21.3 \%$ and $19.5 \%$, respectively. Besides, the cobia liver hydrolysates obtained from EAAE by alcalase, papain, pepsin, and trypsin pretreatment showed scavenge DPPH radical activity with EC50 values of $0.92,1.03,0.83$, and $0.53 \mathrm{mg}$, respectively. After in vitro simulated gastrointestinal digestion, the protein hydrolysates exhibited scavenge DPPH radical activity with EC50 values of 1.15, 1.55, 0.98, and $0.76 \mathrm{mg}$ for alcalase, papain, pepsin, and trypsin, respectively. The study showed that the EAAE process can be used for extracting fish oil from fish waste while simultaneously obtaining the protein hydrolysates with antioxidant activity.
\end{abstract}

Keywords: enzyme-assisted aqueous extraction; proteases; fish oil extraction; fish protein hydrolysates; antioxidant activity; simulated gastrointestinal digestion

\section{Introduction}

Cobia, Rachycentron canadum, is a medium-size marine fish, widely distributed in warm-temperate to tropical waters around the world. Cobia has a high economic value due to its rapid growth and suitability for being cultured in offshore grow-out cages [1,2]. At present, cobia have undergone 
aquaculture in Asia, Southeast Asia, the United States of America, and South America [3]. Cobia are mainly processed into fillets for market sales. The contents of cobia liver, a by-product after fillet processing, possess a high amount of fat, a potential source of fish oil [4]. Fish oil contains long-chain n-3 polyunsaturated fatty acids (PUFAs), especially eicosapentaenoic acid (EPA; C20:5) and docosahexaenoic acid (DHA; C22:6) [5]. The n-3 PUFAs provide great benefits for human health and have important physiological functions, including the prevention of cardiovascular diseases [6,7], improvement of non-alcoholic fatty liver [8,9], anti-inflammatory efficacy [10], and treatment of rheumatoid arthritis [11].

The general methods for extracting fish oil include: Organic solvent extraction [12], pressing method [13], ultrasound-assisted extraction [14], aqueous extraction [15], supercritical carbon dioxide extraction [16], and microwave-assisted extraction [17]. Among these methods, aqueous extraction $(\mathrm{AE})$ is a simple and green process due to its elimination of the problems associated with the use of organic solvents, while possibly improving the oil quality as well [15]. Aqueous extraction uses heating to denature proteins, causing tissue destruction and the subsequent release of the oil. However, compared to solvent extraction, the efficiency of aqueous extraction is lower due to the low solubility of oil in water. An alternative process is using enzyme to enhance the aqueous extraction in order to improve the extraction efficiency of aqueous extraction. The enzyme can disrupt animal or plant tissues, which can accelerate the release of target substances in the aqueous extraction thereby increasing the extraction yield [18]. At present, enzyme-assisted aqueous extraction (EAAE) is often used in the extraction of active ingredients from plants or animals by using cellulase $[19,20]$, pectinase [21], hemicellulase [22], and protease [23]. Many vegetable oils have been extracted by using EAAE, such as sesame oil [24], almond oil [25], soybean oil [26], and peanut oil [27]. However, there is little information available on the use of EAAE for fish oil extraction.

The EAAE process of employing protease on pretreated fish tissue can improve the release of intracellular lipids and simultaneously obtain protein hydrolysates in the aqueous phase. In recent years, many studies have reported that the protein hydrolysates possess antioxidant activity [28,29]. The protein hydrolysates obtained from the hydrolysis of Alaska cod skin by complex protease (protamex) has DPPH free radical scavenging, reducing power, and antioxidant activity [30]; monkfish liver hydrolysate has been demonstrated to have anti-fatigue and antioxidant activity [31]; tuna liver hydrolysates obtained by hydrolysis with flavourzyme have antioxidant activity to protect DNA from oxidative damage induced by hydroxyl free radicals $(\cdot \mathrm{OH})[32,33]$. However, there is no related research on the cobia liver hydrolysates obtained by protease hydrolysis. Several commercial proteases from animal, plant, or microbial sources can be used for this purpose, such as pepsin [34], papain [35], alcalase [36], and trypsin [37]. The enzymatic proteolysis used in aqueous extraction has considerable importance in improving the extraction efficiency. So far, the effects of proteases on the simultaneous extraction of fish oil and derivation of protein hydrolysates from cobia liver by using EAAE have not been reported.

The objective of this study is to investigate the effect of different proteases used in the EAAE process on the extraction yield of fish oil. Alcalase, papain, pepsin, and trypsin were employed to pretreat cobia liver before AE. The process factors affecting the EAAE of cobia liver oil were investigated herein. The cobia liver oils obtained from EAAE and AE processes were compared. In addition, the protein hydrolysates obtained from EAAE were recovered and their antioxidant activities were measured by in vitro simulated gastro-intestinal digestion.

\section{Results and Discussions}

\subsection{Optimal Conditions of Aqueous Extraction}

AE methods of cobia liver oil were performed at a temperature of $95^{\circ} \mathrm{C}$ and substrate water ratio (cobia liver:water) of 1:1.5 (w/w). After cooking for 10 to $30 \mathrm{~min}$, the solution was cooled down to room temperature and centrifuged at $8000 \mathrm{rpm}$ for $20 \mathrm{~min}$. The fish oil on the upper layer was collected and 
weighed. The effect of cooking time on oil extractability is shown in Figure 1a. The oil extractability increased from $9.5 \pm 0.5 \%$ to $16.2 \pm 0.6 \%$ when the cooking time increased from 10 to $15 \mathrm{~min}$. Increasing cooking time after $15 \mathrm{~min}$ had no significant impact on the extraction yield, indicating that cooking for $15 \mathrm{~min}$ was sufficient for aqueous extraction of fish oil. The effect of substrate water ratio was investigated at a temperature of $95^{\circ} \mathrm{C}$ and cooking for $15 \mathrm{~min}$. The result is shown in Figure $1 \mathrm{~b}$ : the substrate water ratio at 1:2 shows the best result with $18.8 \%$ oil extractability. However, the cobia liver contains $48 \%$ fat, indicating that about two-thirds of the cobia liver oil was not extracted under the best conditions of $\mathrm{AE}$. The $\mathrm{AE}$ with a low yield and less effective is due to water takes long to degrade the cell wall of oil-bearing material [38]. Therefore, extraction time of $15 \mathrm{~min}$ and substrate water ratio of 1:2 were used in the EAAE for studying the effect of proteases pretreatment on enhancing extraction efficiency.

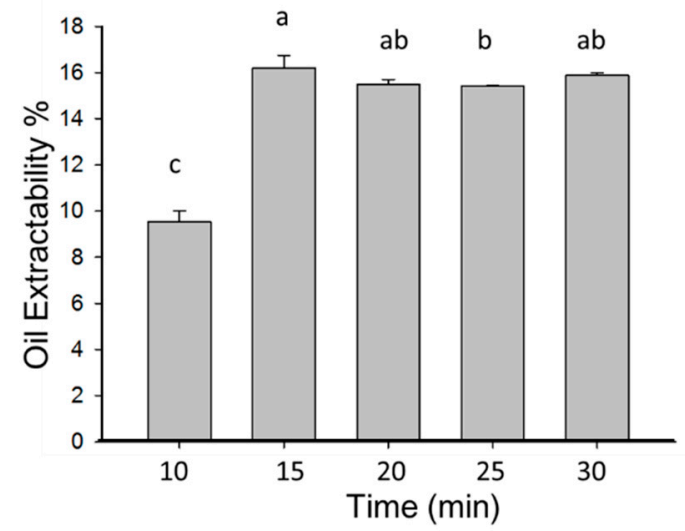

(a)

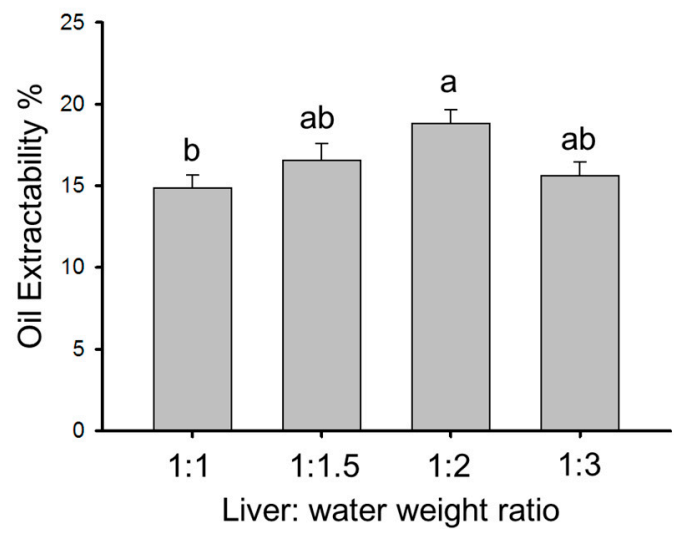

(b)

Figure 1. Effects of (a) cooking time and (b) substrate water ratio on the oil extractability by using AE. The different letters in the graphs indicate a significant difference at $p<0.05$.

\subsection{Effects of Different Proteases Pretreatment on Oil Extractability}

In order to improve the efficiency of AE, EAAE was employed in this study. The EAAE process hydrolyzes cobia liver with protease before AE. Cobia liver was pretreated with $0.5 \%$ of alcalase, papain, pepsin, and trypsin (by cobia liver wt; w/w) under their optimal hydrolysis conditions for $2 \mathrm{~h}$. Then water double the weight of the cobia liver was added, and heated at $95-100{ }^{\circ} \mathrm{C}$ for $15 \mathrm{~min}$ to obtain the upper layer of fish oil. The results are shown in Figure 2. The oil extractability obtained by alcalase, papain, pepsin, and trypsin pretreatment were $32.7 \pm 1.2 \%, 37.0 \pm 1.7 \%, 33.7 \pm 0.4 \%$, and $21.2 \pm 0.2 \%$, respectively. From this result, the maximum oil extractability can be obtained by pretreatment with papain. The oil extractability depends on the extent of protein hydrolysis. Therefore, the protein concentration in the lower layer (aqueous phase) was analyzed to be $17.11 \pm 0.20$, $17.37 \pm 0.09,15.97 \pm 0.24$, and $8.35 \pm 0.24 \mathrm{mg} \mathrm{mL}^{-1}$ for alcalase, papain, pepsin, and trypsin, respectively. The results indicated more protein hydrolyzed by proteases, with higher oil extractability achieved. Therefore, papain was selected for EAAE of cobia liver oil, however it should be kept in mind that alcalase is suitable for industrial scaling-up of EAAE due to it is an industrial enzyme of microbial origin, manufactured in large amounts. Similarly, the sea urchin hydrolyzed by papain also showed higher oil extraction yield in the EAAE process as compared to neutral protease, alkaline protease, and trypsin [39]. 


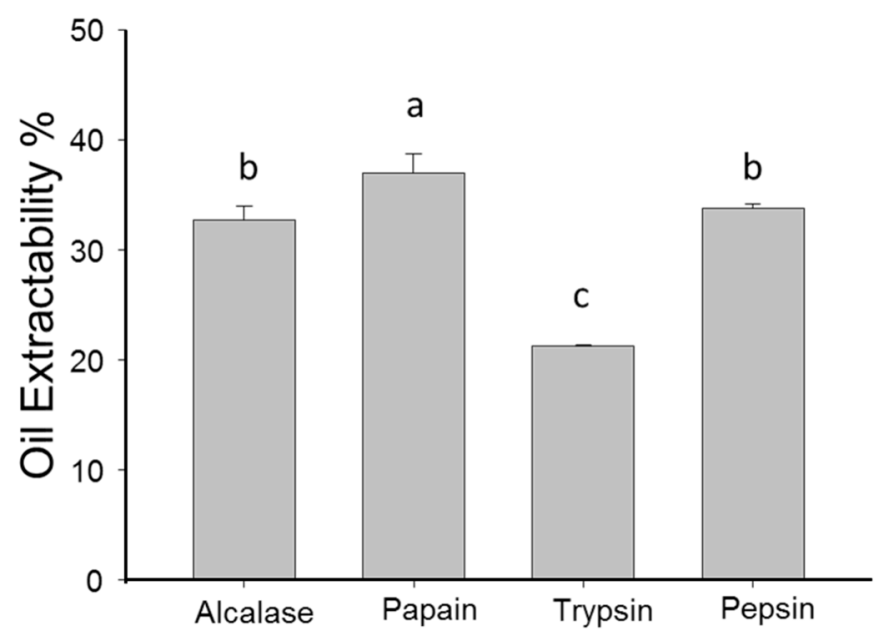

Figure 2. Effect of different commercial proteases used for EAAE on oil extractability. Means with different superscript letters significantly differ $(p<0.05)$. The hydrolysis conditions for alcalase was $\mathrm{pH}=7.5$ and $50{ }^{\circ} \mathrm{C}$, papain was $\mathrm{pH}=6.0$ and $30^{\circ} \mathrm{C}$, pepsin was $\mathrm{pH}=2.0$ and $37^{\circ} \mathrm{C}$, trypsin was $\mathrm{pH}=8.0$ and $37^{\circ} \mathrm{C}$.

\subsection{Optimal Conditions of Enzyme-Assisted Aqueous Extraction}

The EAAE was performed using $0.5 \%$ papain to pretreat cobia liver at $30{ }^{\circ} \mathrm{C}$ with $\mathrm{pH}=3, \mathrm{pH}=4$, $\mathrm{pH}=5, \mathrm{pH}=6$, and $\mathrm{pH}=7$ phosphate buffer for $2 \mathrm{~h}$ before AE. The effect of $\mathrm{pH}$ on the oil extractability is shown in Figure 3a; the results show that the oil extractability increases with $\mathrm{pH}$ and reaches a peak value of $37.7 \pm 0.7 \%$ at $\mathrm{pH}=5$. It has been reported that the polysaccharides extracted from Lycium barbarum and Dictyophora indusiata using cellulose and papain obtained the maximum extraction yield at $\mathrm{pH}=5[40,41]$. Our result is consistent with the previous studies.

The effect of temperature on the oil extractability at $\mathrm{pH}=5$, enzyme concentration of $2 \%$, and hydrolysis time of $2 \mathrm{~h}$, is shown in Figure $3 \mathrm{~b}$. When the temperature increased from $20^{\circ} \mathrm{C}$ to $30{ }^{\circ} \mathrm{C}$, the oil extractability increased from $28.9 \%$ to $36.1 \%$, and then a slight decrease was obtained at temperatures higher than $30{ }^{\circ} \mathrm{C}$ due to the enzyme becoming inactivated at high temperature. According to Rajalakshmi's measurements [42], papain still has 63\% relative activity when incubated at $70{ }^{\circ} \mathrm{C}$ for $2 \mathrm{~h}$. Although the enzyme activity decreased at high temperature, high temperature also increased the enzyme reaction rate. Therefore, the oil extractability was only slightly decreased. As a result, the temperature at $30^{\circ} \mathrm{C}$ was suitable for pretreatment of cobia liver by papain.

The effect of enzyme concentration on the oil extractability at $\mathrm{pH}=5$, temperature of $30{ }^{\circ} \mathrm{C}$, and hydrolysis time of $2 \mathrm{~h}$, is shown in Figure 3c. The oil extractability increased with increased enzyme concentration. The highest oil extractability was achieved with an enzyme concentration of $0.5 \%$. However, while the enzyme concentration increased over $0.5 \%$, the oil extractability did not improve. Generally, the number of active sites increases with the enzyme concentration and more protein are hydrolyzed. However, the number of active sites accessible to the substrate will decrease with the excess of enzyme present, leading to a less significant change in improving the extraction yield. This phenomenon is also found in the enzyme assisted extraction of resveratrol from Polygonum cuspidatum [19,20], polysaccharides from sea cucumber [43], and naked pumpkin seeds [44].

The effect of hydrolysis time on oil extractability at $\mathrm{pH}=5$, temperature of $30^{\circ} \mathrm{C}$ and $0.5 \%$ enzyme concentration is shown in Figure 3d. The hydrolysis time of $2 \mathrm{~h}$ is favorable for papain pretreated cobia liver since a slight decrease was obtained at hydrolysis time higher than $2 \mathrm{~h}$. The results indicated that $2 \mathrm{~h}$ is sufficient for enzyme pretreatment of cobia liver. 

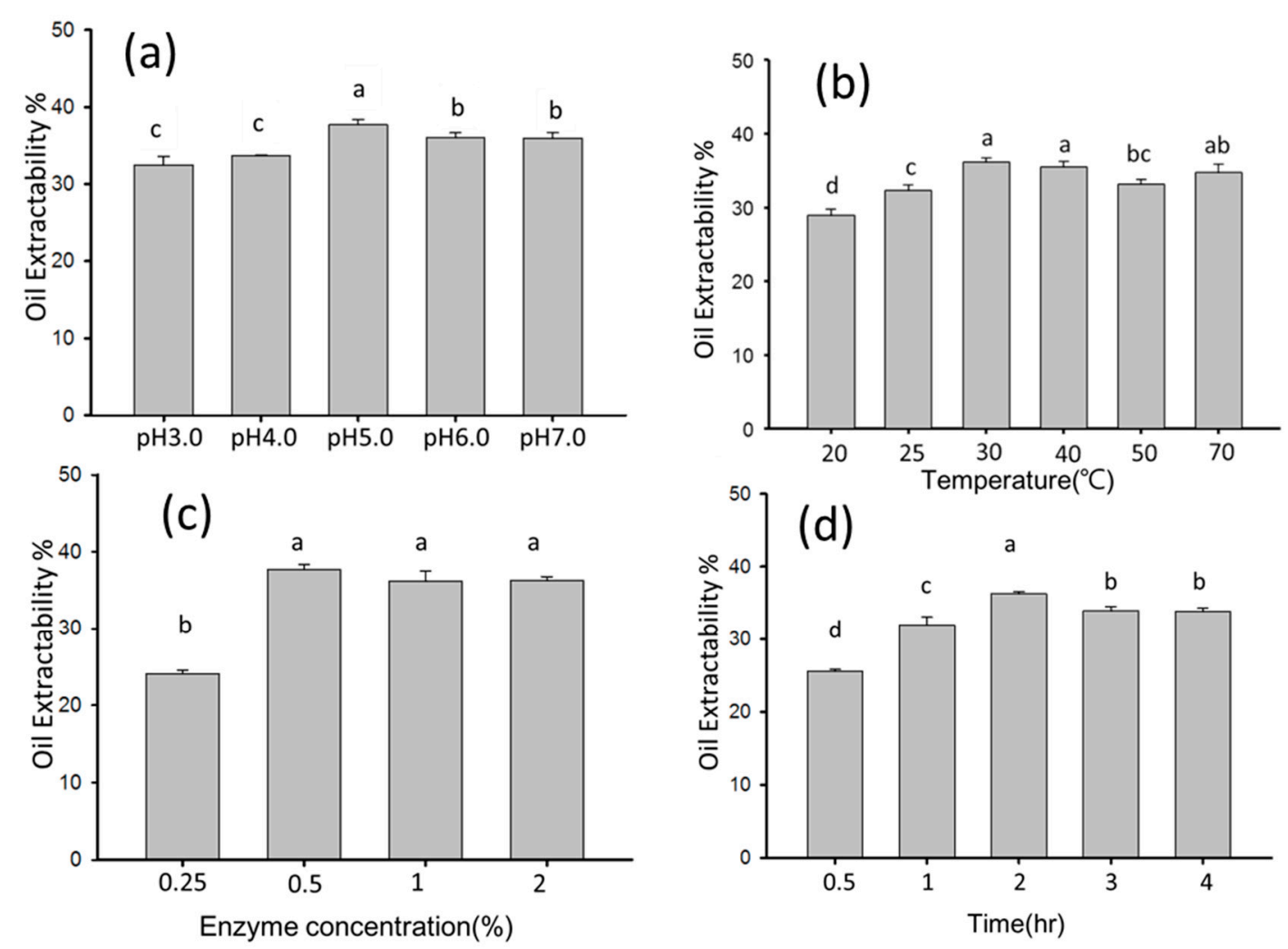

Figure 3. Effect of (a) $\mathrm{pH}$, (b) temperature, (c) enzyme concentration, and (d) hydrolysis time on the oil extractability by papain pretreatment. Means with different superscript letters significantly differ $(p<0.05)$.

After using papain pretreated cobia liver, the cobia liver was freeze-dried to observe the structure changes by scanning electron microscope. The results are shown in Figure 4. There are many small holes on the surface of papain pretreated cobia liver as compared with untreated cobia liver because the papain pretreatment destroyed the tissue of cobia liver. The papain pretreatment made the structure more permeable, so that the lipids could be easily released by EAAE. Sharma et al. used a mixture enzyme (protease, $\alpha$-amylase, and cellulase) in the extraction process to increase the extraction yield of rice bran oil, and the maximum extraction yield was 76-78\% [45]. Huang et al. used a microwave-assisted aqueous saline process to extract Xanthoceras sorbifolium oil, and the maximum extraction yield was $84 \%$ [46]. Samaram et al. used ultrasound-assisted extraction and solvent extraction to extract papaya seed oil, and the maximum extraction yield were $79.1 \%$ and $76.1 \%$, respectively [14]. Sarker et al. used supercritical $\mathrm{CO}_{2}$ extraction of fish oil and obtained an extraction yield of $67 \%$, but the Soxhlet method obtained an extraction yield of $78 \%$ [47]. As compared with these results, our study obtained the oil extractability of $38 \%$ and the extraction yield of $79 \%$, indicating that the EAAE of cobia liver oil has a relatively high extraction efficiency. 


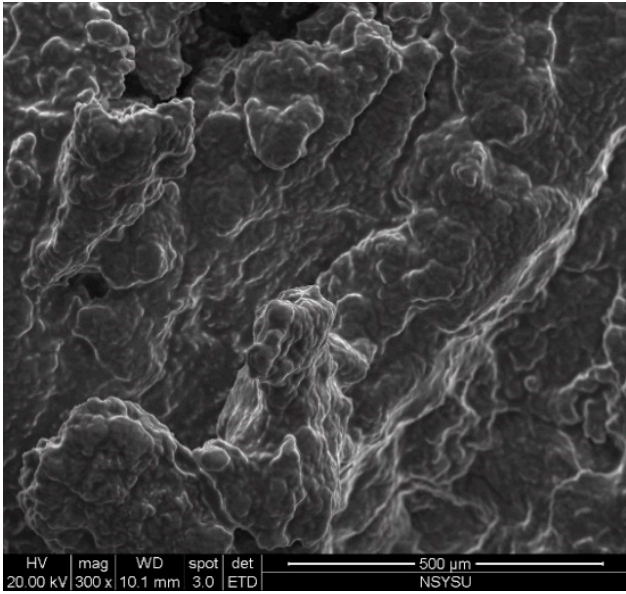

(a)

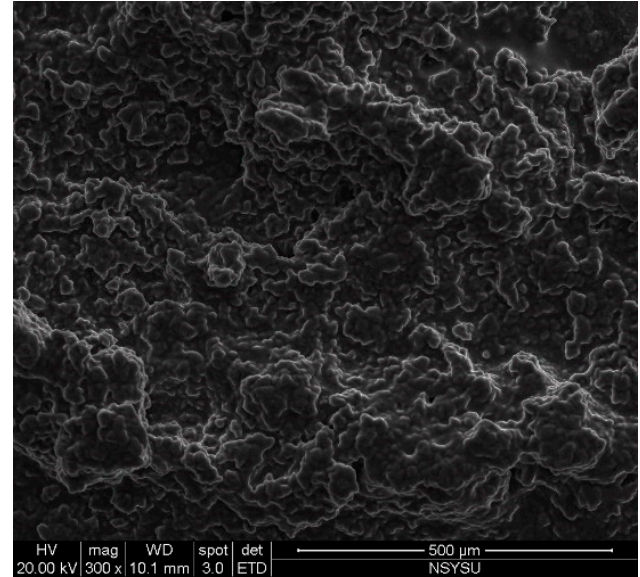

(b)

Figure 4. Scanning electron microscope (SEM) micrographs of (a) cobia liver and (b) cobia liver pretreated with papain.

\subsection{Fatty Acid Composition}

The fatty acid contents of cobia liver oil obtained from AE and EAAE are shown in Table 1 . The cobia liver oils from EAAE contained $41.01-42.12 \%$ saturated fatty acids, $39.20-39.54 \%$ monounsaturated fatty acids, and $18.68-19.45 \%$ polyunsaturated fatty acids. The main fatty acid was oleic acid $\left(\mathrm{C}_{18: 1}\right)$, which contained $33.46-33.93 \%$, followed by palmitic acid $\left(C_{16: 0}\right)$, which contained $28.34-29.12 \%$, and the content of unsaturated fatty acids accounts for more than $55-60 \%$. The contents of the two beneficial fatty acids, EPA and DHA, were $3.80-3.93 \%$ and $13.75-14.37 \%$, respectively. The cobia liver oils obtained from alcalase, papain, pepsin, and trypsin pretreatment showed no significant difference in the content of saturated fatty acids (SFA), monounsaturated fatty acids (MUFA), and polyunsaturated fatty acids (PUFA). Compared to AE, a slight decrease in the content of EPA and DHA was found; this might be due to the enzyme pretreatment slightly decreasing the polyunsaturated fatty acids. The EPA plus DHA contents of both AE and EAAE were 17.55-19.73\%. On the other hand, the EPA plus DHA content of cobia liver oil obtained by solvent extraction was $\sim 23 \%$ [4]. Since the aqueous extraction operated at $95^{\circ} \mathrm{C}$ might degrade EPA and DHA, the content of EPA and DHA is slightly lower than that of the solvent extraction. On the other hand, EPA plus DHA contents of fish oils from tuna, seabass, and cod have been reported to be $\sim 26 \%, \sim 12 \%$, and $\sim 21 \%$, respectively [5]. As compared to other sources of fish oil, the cobia liver can be regarded as a potential raw material for producing EPA- and DHA-enriched fish oil. Furthermore, the cobia liver oil can be divided into fatty acid salts and separated by acetone to concentrate the EPA and DHA [48]. Later, lipase-catalyzed reaction can be used to synthesize EPA and DHA ethyl esters to achieve the required concentration for health food and pharmaceutical specifications [49].

\subsection{Antioxidant Activities of Protein Hydrolysates After In Vitro Simulated Gastro-Intestinal Digestion}

The amino acid composition of cobia liver is shown in Table S1. The higher contents of amino acid in the cobia liver were glutamic acid $(3.93 \mathrm{mg} / \mathrm{g})$, leucine $(3.90 \mathrm{mg} / \mathrm{g})$, and arginine $(3.73 \mathrm{mg} / \mathrm{g})$. Glutamic acid easily donates protons to the electrons in the reaction so that the peptide containing glutamic acid exhibit a strong radical scavenging activity [50]. Several amino acids, such as valine and leucine, have generally been considered as antioxidants [51]. It has been reported that peptides containing lysine or arginine at the $\mathrm{C}$-terminal have high antioxidant activity $[52,53]$. Besides, cobia liver contained histidine $(2.16 \mathrm{mg} / \mathrm{g})$, methionine $(1.76 \mathrm{mg} / \mathrm{g})$, and cystine $(1.71 \mathrm{mg} / \mathrm{g})$. These three amino acids have been reported to be very important to the radical scavenging activity of peptides due to their special structure of characteristics [54]. The amino acid composition of cobia liver showed that the protein 
hydrolysates in the EAAE process can be recovered from the aqueous phase, and has the potential to be used as functional ingredients in different foods.

Table 1. Fatty acid composition of cobia liver oils obtained from EAAE and AE.

\begin{tabular}{|c|c|c|c|c|c|c|c|c|c|c|c|c|c|c|c|}
\hline \multirow{2}{*}{$\frac{\text { Fatty Acid (\%) }}{C_{14: 0}}$} & \multicolumn{3}{|c|}{ Alcalase } & \multicolumn{3}{|c|}{ Papain } & \multicolumn{3}{|c|}{ Pepsin } & \multicolumn{3}{|c|}{ Trypsin } & \multicolumn{3}{|c|}{ Aqueous } \\
\hline & 1.11 & \pm & 0.13 & 1.03 & \pm & 0.04 & 1.07 & \pm & 0.08 & 1.00 & \pm & 0.05 & 1.57 & \pm & 0.22 \\
\hline $\mathrm{C}_{16: 0}$ & 29.12 & \pm & 0.30 & 28.34 & \pm & 0.18 & 29.00 & \pm & 0.13 & 28.63 & \pm & 0.26 & 27.96 & \pm & 1.36 \\
\hline $\mathrm{C}_{18: 0}$ & 11.38 & \pm & 0.12 & 11.17 & \pm & 0.01 & 11.25 & \pm & 0.43 & 11.43 & \pm & 0.15 & 8.05 & \pm & 0.27 \\
\hline $\mathrm{C}_{18: \ln 9}$ & 33.51 & \pm & 0.49 & 33.93 & \pm & 0.01 & 33.46 & \pm & 0.42 & 33.76 & \pm & 0.08 & 32.92 & \pm & 1.04 \\
\hline $\mathrm{C}_{18: 2 \mathrm{n} 6}$ & 0.56 & \pm & 0.02 & 0.56 & \pm & 0.02 & 0.54 & \pm & 0.01 & 0.55 & \pm & 0.03 & 0.84 & \pm & 0.15 \\
\hline$C_{20: 1}$ & 1.23 & \pm & 0.06 & 1.25 & \pm & 0.01 & 1.26 & \pm & 0.01 & 1.25 & \pm & 0.04 & 1.22 & \pm & 0.06 \\
\hline $\mathrm{C}_{22: 0}$ & 0.18 & \pm & 0.01 & 0.15 & \pm & 0.03 & 0.16 & \pm & 0.00 & 0.18 & \pm & 0.04 & 0.11 & \pm & 0.03 \\
\hline $\mathrm{C}_{20: 5 \mathrm{n} 3}(\mathrm{EPA})$ & 3.80 & \pm & 0.08 & 3.93 & \pm & 0.03 & 3.81 & \pm & 0.07 & 3.86 & \pm & 0.15 & 4.15 & \pm & 0.65 \\
\hline $\mathrm{C}_{22: 6 \mathrm{n} 3}(\mathrm{DHA})$ & 13.75 & \pm & 0.20 & 14.37 & \pm & 0.21 & 14.05 & \pm & 0.18 & 14.13 & \pm & 0.29 & 15.59 & \pm & 1.52 \\
\hline $\mathrm{SFA}^{2}$ & 42.12 & \pm & $0.43^{1 \mathrm{a}}$ & 41.01 & \pm & $0.21^{\mathrm{a}}$ & 41.82 & \pm & $0.33^{\mathrm{a}}$ & 41.58 & \pm & $0.38^{a}$ & 37.92 & & $1.44^{b}$ \\
\hline
\end{tabular}

${ }^{1}$ All values represent the mean of three replicates \pm standard deviation. Values with different superscript letters within a row significantly differ $(p<0.05) .{ }^{2}$ SFA $=$ Saturated fatty acids, MUFA = Monounsaturated fatty acids, PUFA $=$ Polyunsaturated fatty acids.

In recent years, more and more studies have confirmed that the protein hydrolysates have antioxidant activity that helps to protect human tissues and organs from hydroxyl free radicals $(\cdot \mathrm{OH})$, peroxides free radicals $(\cdot \mathrm{OOR})$, superoxide anion free radicals $\left(\mathrm{O}_{2}^{-} \cdot\right)$; peroxynitrite $(\mathrm{ONOO}-)$ and other active oxygen and nitrogen substances cause oxidative damage [55]. The protein hydrolysates in the aqueous phase of the EAAE process pretreated by different proteases were recovered by freeze drying. The protein hydrolysates were then digested with simulated gastric fluid (SGF) and simulated intestinal fluid (SIF) in order to determine their antioxidative function after simulated gastro-intestinal digestion. The antioxidant activities of protein hydrolysates obtained from EAAE pretreated by alcalase, papain, pepsin, and trypsin were examined by 2,2-diphenyl-1-picrylhydrazyl (DPPH) radical scavenging activity, and ferrous-ion chelating activity.

The DPPH radical-scavenging activity of cobia liver protein hydrolysates is shown in Figure 5. The effective concentration scavenges 50\% DPPH radical (EC50) of alcalase, papain, pepsin, and trypsin hydrolysates were $0.92 \mathrm{mg}, 1.03 \mathrm{mg}, 0.83 \mathrm{mg}$, and $0.53 \mathrm{mg}$, respectively. After simulated gastro-intestinal digest, the EC50 of alcalase, papain, pepsin, and trypsin hydrolysates were $1.15 \mathrm{mg}, 1.55 \mathrm{mg}, 0.98 \mathrm{mg}$, and $0.76 \mathrm{mg}$, respectively. Although a slight increase in EC50 was found, the hydrolysates still showed good ability to scavenge free radicals. During the simulated gastrointestinal digestion, the alcalase, papain, pepsin, and trypsin hydrolysates were hydrolyzed by gastro-intestinal enzymes to further degrade into tripeptides, dipeptides, and even amino acids. Thus, the hydrophilic ends of amino acids were exposed, resulting in increasing hydrophilicity, making it difficult to react with the lipophilic DPPH free radicals, resulting in decreased scavenging ability [56]. The EC50 of protein hydrolysates from peanut [57], fish visceral waste [58], and skipjack tuna [59] have been reported to be $23 \mathrm{mg}$, $3.47 \mathrm{mg}$, and $4.54 \mathrm{mg}$, respectively. Compared to those results, cobia liver hydrolysates have good DPPH radical scavenging ability. 


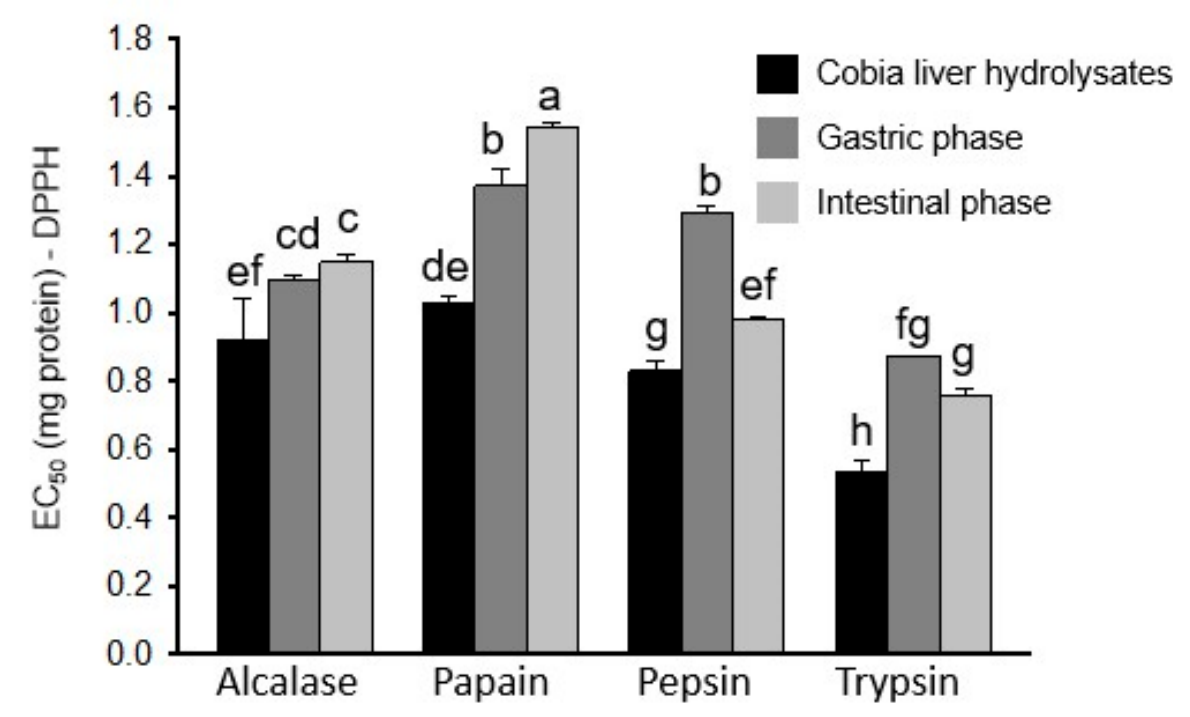

Figure 5. Effect of simulated gastro-intestinal digestion in vitro on $\mathrm{EC}_{50}$ values (effective concentration scavenges 50\% radical) for DPPH radical scavenging properties of cobia liver hydrolysates obtained from AE by alcalase, papain, pepsin, and trypsin treatment. Means with different superscript letters significantly differ $(p<0.05)$.

Transition metals, such as $\mathrm{Fe}^{2+}$ and $\mathrm{Cu}^{2+}$, can catalyze the lipid oxidation reactions to form the hydroxyl free radicals $(\cdot \mathrm{OH})$ and superoxide anion free radicals $\left(\mathrm{O}_{2}^{-} \cdot\right)$ because these metals can directly react with fatty acids by reducing the energy required, which accelerates the lipid peroxidation chain reaction. Moreover, the decomposition of lipid peroxides is catalyzed by $\mathrm{Fe}^{2+}$, which leads to the formation of reactive alkoxyl radicals and volatile oxidation products with rancid odor, such as short-chain aldehydes, ketones, acids, and esters [60]. Therefore, the chelation of metal ions can effectively reduce lipid oxidation. The ferrous chelating ability of cobia liver hydrolysates (2000 ppm) is shown in Figure 6. After simulated gastro-intestinal digestion, the ferrous chelating ability of alcalase, papain, pepsin, and trypsin hydrolysates greatly increased. The trypsin hydrolysates have better ability to chelate ferrous ions, followed by the alcalase hydrolysates; the chelating ability was increased after simulated gastric digestion. Wu et al. have pointed out that the molecular weight and amino acid composition of the hydrolysates may affect the antioxidant and metal chelating activity [61]. The molecular weight of gelatin hydrolysates less than $3 \mathrm{kDa}$ showed the better chelating ability [62]. Based on the above results, it can be seen that the EAAE process uses of enzymes to pretreat the cobia liver can increase the oil extraction rate as compared to the AE. The protein hydrolysates showed a good ability to scavenge DPPH free radicals; ferrous chelation can prevent lipid oxidation and can used as an ingredient in formulate nutraceuticals or functional foods to reduce the oxidative stress, apart from providing balanced amino acids. 


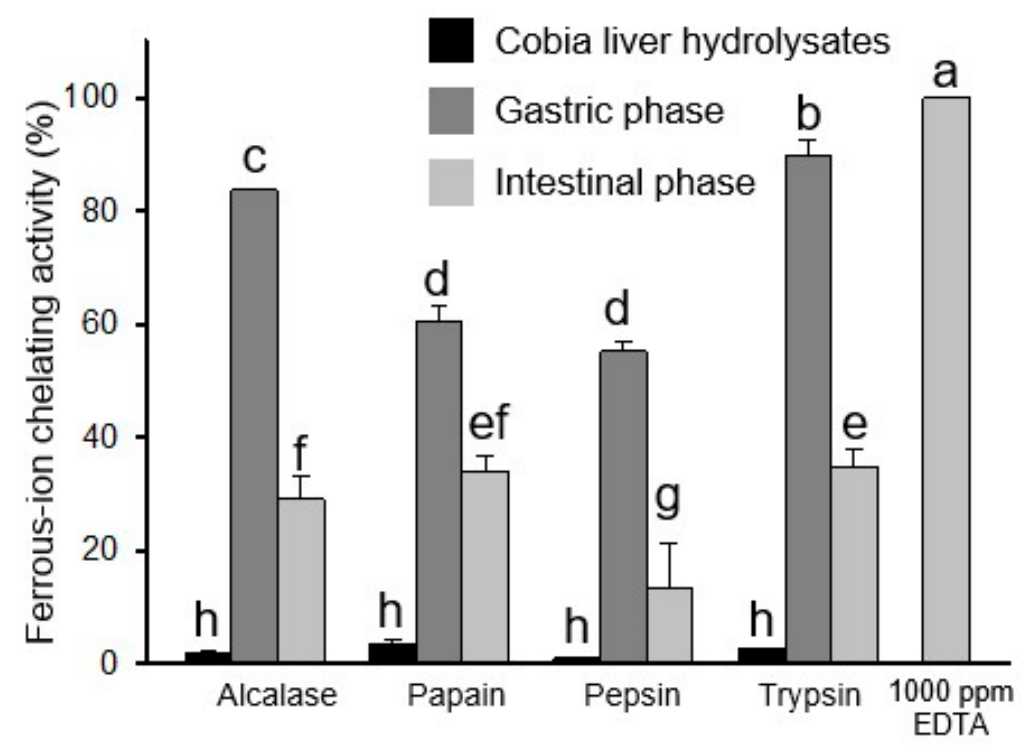

Figure 6. Effect of simulated gastro-intestinal digestion in vitro on ferrous-ion chelating activity of cobia liver hydrolysates obtained from AE by alcalase, papain, pepsin, and trypsin treatment. $1000 \mathrm{ppm}$ EDTA was used as a positive control. Means with different superscript letters significantly differ $(p<0.05)$.

\section{Materials and Methods}

\subsection{Materials}

Cobia livers were purchased from cobiahome Inc. (Pingtung, Taiwan) and stored at $-20{ }^{\circ} \mathrm{C}$ as ca. $1 \mathrm{~kg}$ packages in sealed plastic bags until used. The composition of cobia liver was $48.14 \%$ fat, $42.02 \%$ moisture, $9.23 \%$ protein, and $0.61 \%$ ash. Alcalase $\left(3.03 \mathrm{U} \mathrm{mL}^{-1}\right)$ was purchased from Merck Millipore (Billerica, MA, USA). Papain (3.3 U mg ${ }^{-1}$ ), pepsin (1200 U mg ${ }^{-1}$ ), pancreatin, bile bovine, $\mathrm{BF}_{3}$-methanol reagent $\left(14 \% \mathrm{BF}_{3}\right.$ in $\left.\mathrm{CH}_{3} \mathrm{OH}, \mathrm{w} / \mathrm{v}\right)$, fatty acid methyl ester standards (Supelco 37 Component FAME Mix, catalog no. 47885) and L-amino acid standards were purchased from Sigma-Aldrich (St. Louis, MO, USA). Trypsin (2000 U g ${ }^{-1}$ ) was purchased from HiMedia Laboratories (Mumbai, India). DPPH (2,2-Diphenyl-1-picrylhydrazyl) and $p$-anisidine were purchased from Alfa Aesar (Tewksbury, MA, USA). Unless otherwise noted, all reagents and chemicals were of analytical grade.

\subsection{Aqueous Extraction}

The cobia liver was minced in an Osterizer Galaxie blender (Oster Corporation, Milwaukee, WI, USA). $100 \mathrm{~g}$ of minced cobia liver was mixed with different amounts of water (1:1 to $1: 3 \mathrm{w} / \mathrm{v})$ then cooked at $95^{\circ} \mathrm{C}$ in the water bath for 10 to $30 \mathrm{~min}$. The resulting sample was centrifuged at $8000 \mathrm{rpm}$ for $20 \mathrm{~min}$, and the upper oil layer was collected. The oil extractability (\%) was expressed as: weight of oil $(\mathrm{g})$ per weight of wet cobia liver $(\mathrm{g}) \times 100$.

\subsection{Enzyme-Assisted Aqueous Extraction}

EAAE was carried out by using different commercial proteases to hydrolyze cobia liver before oil extraction. Enzymatic hydrolysis was carried out using different commercial proteases at their optimum $\mathrm{pH}$ and temperature: alcalase $\left(\mathrm{pH}=7.5,50^{\circ} \mathrm{C}\right)$, papain $\left(\mathrm{pH}=6,30{ }^{\circ} \mathrm{C}\right)$, pepsin $(\mathrm{pH}=2$, $\left.37^{\circ} \mathrm{C}\right)$, and trypsin $\left(\mathrm{pH}=8,37^{\circ} \mathrm{C}\right)$. Briefly, $100 \mathrm{~g}$ of minced cobia liver was mixed with $100 \mathrm{~mL} 10 \mathrm{mM}$ phosphate buffers of different $\mathrm{pH}$. The mixture was added with enzyme $(0.5 \%$ by cobia liver wt $)$ and then incubated at optimum temperature with constant shaking at $120 \mathrm{rpm}$ for $2 \mathrm{~h}$. After that, $100 \mathrm{~mL}$ water was added to the mixture then cooked at $95^{\circ} \mathrm{C}$ for $15 \mathrm{~min}$. The resulting sample was centrifuged 
at $8000 \mathrm{rpm}$ for $20 \mathrm{~min}$, and the upper oil layer was collected. The lower aqueous phase was recovered and freeze-dried to obtain the protein hydrolysates.

\subsection{In Vitro Simulated Gastro-Intestinal Digestion}

Simulated gastro-intestinal digestion was performed according to the method described by Minekus et al. [63], with some minor modifications. The simulated gastric fluid (SGF) electrolyte stock solution was composed of $6.9 \mathrm{mM} \mathrm{KCl}, 0.9 \mathrm{mM} \mathrm{KH}_{2} \mathrm{PO}_{4}, 25 \mathrm{mM} \mathrm{NaHCO}_{3}, 47.2 \mathrm{mM} \mathrm{NaCl}, 0.1 \mathrm{mM}$ $\mathrm{MgCl}_{2}\left(\mathrm{H}_{2} \mathrm{O}\right)_{6}, 0.5 \mathrm{mM}\left(\mathrm{NH}_{4}\right)_{2} \mathrm{CO}_{3}$, and $15.6 \mathrm{mM} \mathrm{HCl}$. The simulated intestinal fluid (SIF) electrolyte stock solution was composed of $6.8 \mathrm{mM} \mathrm{KCl}, 0.8 \mathrm{mM} \mathrm{KH}_{2} \mathrm{PO}_{4}, 85 \mathrm{mM} \mathrm{NaHCO}_{3}, 38.4 \mathrm{mM} \mathrm{NaCl}$, $0.33 \mathrm{mM} \mathrm{MgCl}_{2}\left(\mathrm{H}_{2} \mathrm{O}\right)_{6}$, and $8.4 \mathrm{mM} \mathrm{HCl}$. The simulated gastric digestion was prepared as follows: $10 \mathrm{~mL}$ of protein hydrolysates $\left(2 \mathrm{mg} \mathrm{mL}^{-1}\right)$ was mixed with $7.5 \mathrm{~mL}$ of SGF electrolyte stock solution, $1.6 \mathrm{~mL}$ of pepsin solution ( $25000 \mathrm{U} \mathrm{mL}^{-1}$ in SGF electrolyte stock solution), $5 \mu \mathrm{L}$ of $0.3 \mathrm{M} \mathrm{CaCl}_{2}, 0.2 \mathrm{~mL}$ of $1 \mathrm{M} \mathrm{HCl}$, and $0.695 \mathrm{~mL}$ of water. The mixture was incubated at $37^{\circ} \mathrm{C}$ in a shaking water bath for $2 \mathrm{~h}$. After simulated gastric digestion, $11 \mathrm{~mL}$ of SIF electrolyte stock solution, $5.0 \mathrm{~mL}$ of pancreatin solution (800 $\mathrm{U} \mathrm{mL}^{-1}$ in SIF electrolyte stock solution), $2.5 \mathrm{~mL}$ of $160 \mathrm{mM}$ bile, $40 \mu \mathrm{L}$ of $0.3 \mathrm{M} \mathrm{CaCl}_{2}, 0.15 \mathrm{~mL}$ of $1 \mathrm{M} \mathrm{NaOH}$, and $1.31 \mathrm{~mL}$ of water were added to the $20 \mathrm{~mL}$ of gastric chyme for simulated intestinal digestion. The mixture was further incubated at $37^{\circ} \mathrm{C}$ in a shaking water bath for $2 \mathrm{~h}$. After that, the mixture was kept in boiling water for $10 \mathrm{~min}$ to terminate the digestion. The mixture was filtered through a G3 funnel, and the filtrate was used for antioxidant activity.

\subsection{Antioxidant Activity Analysis}

The DPPH radical scavenging activity was measured using the method described previously [64], with some minor modifications. Briefly, $1 \mathrm{~mL}$ of the sample was mixed with $1 \mathrm{~mL} 0.1 \mathrm{mM}$ freshly prepared DPPH solution (in ethanol) and shaken vigorously for $1 \mathrm{~min}$ then placed the solution in the dark at room temperature for $30 \mathrm{~min}$. The all sample solutions were measured their absorbance at $517 \mathrm{~nm}$ using a UV/VIS spectrophotometer (Hitachi U-2900, Tokyo, Japan). The DPPH radical scavenging activity was calculated using the equation

$$
\text { Scavenging activity }(\%)=\left[1-\left(\mathrm{A}_{\text {sample }} / \mathrm{A}_{\text {control }}\right)\right] \times 100
$$

where $\mathrm{A}_{\text {sample }}$ is the absorbance of the methanol solution of DPPH with tested samples, and $\mathrm{A}_{\text {control }}$ represents the absorbance of the methanol solution of DPPH without the sample.

The ferrous ion chelating ability was measured using the method described previously [65], with some minor modifications. Briefly, $1 \mathrm{~mL}$ of sample was mixed with $0.1 \mathrm{~mL}$ of $2 \mathrm{mM}$ ferrous chloride and $3.7 \mathrm{~mL}$ of methanol. Then addition of $0.2 \mathrm{~mL}$ of $5 \mathrm{mM}$ ferrozine to the mixture to start the reaction, and the mixture was shaken vigorously before being left to stand at room temperature for $10 \mathrm{~min}$. Absorbance of the resulting solution was measured at $562 \mathrm{~nm}$. A complex of ferrous/ferrozine showed strong absorbance at $562 \mathrm{~nm}$. The ferrous ion chelating ability was calculated using the equation

$$
\text { Ferrous ion chelating ability }(\%)=\left[1-\left(\mathrm{A}_{\text {sample }} / \mathrm{A}_{\text {control }}\right)\right] \times 100
$$

where $\mathrm{A}_{\text {sample }}$ is the absorbance of the solution with tested samples, and $\mathrm{A}_{\text {control }}$ represents the absorbance of the solution without the sample.

\subsection{Analysis}

Fatty acid composition of extracted cobia oil was measured by GC method as described previously [4]. Scanning electron microscopy (SEM) of freeze-dried cobia liver before and after EAEE was analyzed by an environmental scanning electron microscope (ESEM; FEI Quanta-200, Czech Republic). The amino acid composition of cobia liver was determined using an HPLC system (Hitachi, Tokyo, Japan) equipped with diode array detector (L-2455) and with fluorescence detector 
(L-2480) set at excitation wavelength $348 \mathrm{~nm}$ and emission cutoff filter at $450 \mathrm{~nm}$. The amino acids were derivatized by $o$-phtalaldehyde and 9-fluorenylmethyloxycarbonyl chloride [66,67]. The derivatized amino acids were separated by using an Inertsil ODS-3 column $(5 \mu \mathrm{M}, 250 \times 4.6 \mathrm{~mm})$.

\subsection{Statistical Analysis}

The experimental data was analyzed by one way analysis of variance (AVOVA) using JMP software (SAS Institute Inc., Cary, NC, USA) and the mean in each group was compared by student's test; significance was defined at $P<0.05$.

\section{Conclusions}

This study developed an environmentally friendly method, EAAE, which can be effectively used to recover lipids and protein hydrolysate from fish processing waste. EAAE using water to extract fish oil, thus reducing the organic solvent usage, is a green process. Four proteases-alcalase, papain, pepsin, and trypsin - were used to improve the oil extractability by AE. EAAE of cobia liver oil by papain pretreatment at optimum conditions obtained $38 \%$ oil extractability. EAAE greatly improved the extraction efficiency; the oil extractability was double compared to AE (18.8\%). The fatty acid profile showed that cobia liver oil has rich sources of PUFA with several health benefits that can provide a better alternative for fish oil. The protein hydrolysates obtained from the aqueous phase of EAAE process had antioxidant activity, the in vitro simulated gastro-intestinal digestion confirmed the ability of scavenging DPPH radical and chelating ferrous. Many studies have reported that the protein hydrolysates have the functions of anti-fatigue, anti-cancer, and anti-hypertensive activity. The results of this study showed that the cobia liver hydrolysates have anti-oxidation function. Therefore, the other biological activities of cobia liver hydrolysates can be further explored. Finally, EAAE simultaneously obtained the lipids and protein hydrolysates in the fish processing waste and hence could be a better green process in effectively managing waste from fish processing.

Supplementary Materials: The following is available online at http://www.mdpi.com/2073-4344/10/11/1323/s1, Table S1: Amino acid content of cobia liver.

Author Contributions: Conceptualization, C.-H.K., M.-L.T. and P.-P.S.; Methodology, Y.-H.W.; Formal analysis, Y.-H.W.; Investigation, Y.-H.W.; Resources, C.-L.L. and W.-C.K.; Data curation, M.-L.T.; Writing一 original draft preparation, C.-H.K.; Writing-review and editing, C.-H.K. and P.-P.S.; Supervision, C.-H.K., M.-L.T. and P.-P.S. All authors have read and agreed to the published version of the manuscript.

Funding: This research was funded by Ministry of Science and Technology of Taiwan, grant number MOST 104-2218-E-022-001-MY2 and 109-2221-E-992-048.

Conflicts of Interest: The authors declare no conflict of interest.

\section{References}

1. Huang, C.-T.; Miao, S.; Nan, F.-H.; Jung, S.-M. Study on regional production and economy of cobia Rachycentron canadum commercial cage culture. Aquac. Int. 2011, 19, 649-664. [CrossRef]

2. Wu, Y.-S.; Chen, Y.-Y.; Ueng, P.-S.; Nan, F.-H. Effects of medicinal herbs "Plantago asiatica", "Houttuynia cordata" and "Mentha haplocalyx" on non-specific immune responses of cobia (Rachycentron canadum). Fish Shellfish Immunol. 2016, 58, 406-414. [CrossRef] [PubMed]

3. FAO. Cultured Aquatic Species Information Programme Rachycentron canadum (Linnaeus, 1766). Available online: http://www.fao.org/fishery/culturedspecies/Rachycentron_canadum/en (accessed on 22 October 2020).

4. Kuo, C.H.; Liao, H.Z.; Wang, Y.H.; Wang, H.M.D.; Shieh, C.J.; Tseng, C.Y. Highly efficient extraction of EPA/DHA-enriched oil from cobia liver using homogenization plus sonication. Eur. J. Lipid Sci. Technol. 2017, 119, 1600466. [CrossRef]

5. Šimat, V.; Vlahović, J.; Soldo, B.; Skroza, D.; Ljubenkov, I.; Generalić Mekinić, I. Production and refinement of omega-3 rich oils from processing by-products of farmed fish species. Foods 2019, 8, 125. [CrossRef] [PubMed] 
6. Manuelli, M.; Della Guardia, L.; Cena, H. Enriching diet with n-3 PUFAs to help prevent cardiovascular diseases in healthy adults: Results from clinical trials. Int. J. Mol. Sci. 2017, 18, 1552. [CrossRef]

7. Méndez, L.; Dasilva, G.; Taltavull, N.; Romeu, M.; Medina, I. Marine lipids on cardiovascular diseases and other chronic diseases induced by diet: An insight provided by proteomics and lipidomics. Mar. Drugs 2017, 15, 258. [CrossRef]

8. De Castro, G.S.; Deminice, R.; Simões-Ambrosio, L.M.C.; Calder, P.C.; Júnior, A.A.J.; Vannucchi, H. Dietary docosahexaenoic acid and eicosapentaenoic acid influence liver triacylglycerol and insulin resistance in rats fed a high-fructose diet. Mar. Drugs 2015, 13, 1864-1881. [CrossRef]

9. Yang, M.; Gong, S.; Ye, S.Q.; Lyman, B.; Geng, L.; Chen, P.; Li, D.-Y. Non-alcoholic fatty liver disease in children: Focus on nutritional interventions. Nutrients 2014, 6, 4691-4705. [CrossRef]

10. Duttaroy, A.K. Docosahexaenoic acid supports feto-placental growth and protects cardiovascular and cognitive function: A mini review. Eur. J. Lipid Sci. Technol. 2016, 118, 1439-1449. [CrossRef]

11. Dawczynski, C.; Dittrich, M.; Neumann, T.; Goetze, K.; Welzel, A.; Oelzner, P.; Völker, S.; Schaible, A.; Troisi, F.; Thomas, L. Docosahexaenoic acid in the treatment of rheumatoid arthritis: A double-blind, placebo-controlled, randomized cross-over study with microalgae vs. sunflower oil. Clin. Nutr. 2018, 37, 494-504. [CrossRef]

12. Efthymiopoulos, I.; Hellier, P.; Ladommatos, N.; Kay, A.; Mills-Lamptey, B. Effect of solvent extraction parameters on the recovery of oil from spent coffee grounds for biofuel production. Waste Biomass Valorization 2019, 10, 253-264. [CrossRef] [PubMed]

13. Soto, C.; Chamy, R.; Zuniga, M. Enzymatic hydrolysis and pressing conditions effect on borage oil extraction by cold pressing. Food Chem. 2007, 102, 834-840. [CrossRef]

14. Samaram, S.; Mirhosseini, H.; Tan, C.P.; Ghazali, H.M. Ultrasound-assisted extraction (UAE) and solvent extraction of papaya seed oil: Yield, fatty acid composition and triacylglycerol profile. Molecules 2013, 18, 12474-12487. [CrossRef] [PubMed]

15. Khoei, M.; Chekin, F. The ultrasound-assisted aqueous extraction of rice bran oil. Food Chem. 2016, 194, 503-507. [CrossRef] [PubMed]

16. Xu, W.; Chu, K.; Li, H.; Chen, L.; Zhang, Y.; Tang, X. Extraction of Lepidium apetalum seed oil using supercritical carbon dioxide and anti-oxidant activity of the extracted oil. Molecules 2011, 16, 10029-10045. [CrossRef]

17. Hu, B.; Li, C.; Zhang, Z.; Zhao, Q.; Zhu, Y.; Su, Z.; Chen, Y. Microwave-assisted extraction of silkworm pupal oil and evaluation of its fatty acid composition, physicochemical properties and antioxidant activities. Food Chem. 2017, 231, 348-355. [CrossRef]

18. Rhein-Knudsen, N.; Ale, M.T.; Meyer, A.S. Seaweed hydrocolloid production: An update on enzyme assisted extraction and modification technologies. Mar. Drugs 2015, 13, 3340-3359. [CrossRef]

19. Kuo, C.-H.; Chen, B.-Y.; Liu, Y.-C.; Chen, J.-H.; Shieh, C.-J. Production of resveratrol by piceid deglycosylation using cellulase. Catalysts 2016, 6, 32. [CrossRef]

20. Lin, J.-A.; Kuo, C.-H.; Chen, B.-Y.; Li, Y.; Liu, Y.-C.; Chen, J.-H.; Shieh, C.-J. A novel enzyme-assisted ultrasonic approach for highly efficient extraction of resveratrol from Polygonum cuspidatum. Ultrason. Sonochem. 2016, 32, 258-264. [CrossRef]

21. Huo, S.; Wang, Z.; Cui, F.; Zou, B.; Zhao, P.; Yuan, Z. Enzyme-assisted extraction of oil from wet microalgae Scenedesmus sp. G4. Energies 2015, 8, 8165-8174. [CrossRef]

22. Encalada, A.M.I.; Pérez, C.D.; Flores, S.K.; Rossetti, L.; Fissore, E.N.; Rojas, A.M. Antioxidant pectin enriched fractions obtained from discarded carrots (Daucus carota L.) by ultrasound-enzyme assisted extraction. Food Chem. 2019, 289, 453-460. [CrossRef] [PubMed]

23. Ihua, M.W.; Guihéneuf, F.; Mohammed, H.; Margassery, L.M.; Jackson, S.A.; Stengel, D.B.; Clarke, D.J.; Dobson, A.D. Microbial population changes in decaying Ascophyllum nodosum result in macroalgal-polysaccharide-degrading bacteria with potential applicability in enzyme-assisted extraction technologies. Mar. Drugs 2019, 17, 200. [CrossRef] [PubMed]

24. Latif, S.; Anwar, F. Aqueous enzymatic sesame oil and protein extraction. Food Chem. 2011, 125, 679-684. [CrossRef]

25. Souza, T.S.P.; Dias, F.F.; Koblitz, M.G.B.; Bell, J.M.L.N.D.M. Aqueous and enzymatic extraction of oil and protein from almond cake: A comparative study. Processes 2019, 7, 472. [CrossRef] 
26. Han, L.; Zhang, S.; Qi, B.-K.; Li, H.; Xie, F.-Y.; Li, Y. Molecular distillation-induced deacidification of soybean oil isolated by enzyme-assisted aqueous extraction: Effect of distillation parameters. Appl. Sci. 2019, 9, 2123. [CrossRef]

27. Deng, B.X.; Li, B.; Li, X.D.; Zaaboul, F.; Jiang, J.; Li, J.W.; Li, Q.; Cao, P.R.; Liu, Y.F. Using short-wave infrared radiation to improve aqueous enzymatic extraction of peanut oil: Evaluation of peanut cotyledon microstructure and oil quality. Eur. J. Lipid Sci. Technol. 2018, 120, 1700285. [CrossRef]

28. Karamać, M.; Kosińska-Cagnazzo, A.; Kulczyk, A. Use of different proteases to obtain flaxseed protein hydrolysates with antioxidant activity. Int. J. Mol. Sci. 2016, 17, 1027. [CrossRef]

29. Chow, C.J.; Yang, J.I. The effect of process variables for production of cobia (Rachycentron canadum) skin gelatin hydrolysates with antioxidant properties. J. Food Biochem. 2011, 35, 715-734. [CrossRef]

30. Jia, J.; Zhou, Y.; Lu, J.; Chen, A.; Li, Y.; Zheng, G. Enzymatic hydrolysis of Alaska pollack (Theragra chalcogramma) skin and antioxidant activity of the resulting hydrolysate. J. Sci. Food Agric. 2010, 90, 635-640. [CrossRef]

31. Xu, J.; Li, Y.; Regenstein, J.; Su, X. In vitro and in vivo anti-oxidation and anti-fatigue effect of monkfish liver hydrolysate. Food Biosci. 2017, 18, 9-14. [CrossRef]

32. Ahn, C.B.; Lee, K.H.; Je, J.Y. Enzymatic production of bioactive protein hydrolysates from tuna liver: Effects of enzymes and molecular weight on bioactivity. Int. J. Food Sci. Technol. 2010, 45, 562-568. [CrossRef]

33. Je, J.-Y.; Lee, K.-H.; Lee, M.H.; Ahn, C.-B. Antioxidant and antihypertensive protein hydrolysates produced from tuna liver by enzymatic hydrolysis. Food Res. Int. 2009, 42, 1266-1272. [CrossRef]

34. Fan, J.; He, J.; Zhuang, Y.; Sun, L. Purification and identification of antioxidant peptides from enzymatic hydrolysates of tilapia (Oreochromis niloticus) frame protein. Molecules 2012, 17, 12836-12850. [CrossRef] [PubMed]

35. Song, L.; Li, T.; Yu, R.; Yan, C.; Ren, S.; Zhao, Y. Antioxidant activities of hydrolysates of Arca subcrenata prepared with three proteases. Mar. Drugs 2008, 6, 607-619. [CrossRef]

36. Xu, S.; Shen, Y.; Li, Y. Antioxidant activities of sorghum kafirin alcalase hydrolysates and membrane/gel filtrated fractions. Antioxidants 2019, 8, 131. [CrossRef]

37. Yang, J.-I.; Ho, H.-Y.; Chu, Y.-J.; Chow, C.-J. Characteristic and antioxidant activity of retorted gelatin hydrolysates from cobia (Rachycentron canadum) skin. Food Chem. 2008, 110, 128-136. [CrossRef]

38. Mwaurah, P.W.; Kumar, S.; Kumar, N.; Attkan, A.K.; Panghal, A.; Singh, V.K.; Garg, M.K. Novel oil extraction technologies: Process conditions, quality parameters, and optimization. Compr. Rev. Food Sci. Food Saf. 2020, 19, 3-20. [CrossRef]

39. Zhu, B.W.; Qin, L.; Zhou, D.Y.; Wu, H.T.; Wu, J.; Yang, J.F.; Li, D.M.; Dong, X.P.; Murata, Y. Extraction of lipid from sea urchin (Strongylocentrotus nudus) gonad by enzyme-assisted aqueous and supercritical carbon dioxide methods. Eur. Food Res. Technol. 2010, 230, 737-743. [CrossRef]

40. Zhang, J.; Jia, S.; Liu, Y.; Wu, S.; Ran, J. Optimization of enzyme-assisted extraction of the Lycium barbarum polysaccharides using response surface methodology. Carbohydr. Polym. 2011, 86, 1089-1092. [CrossRef]

41. Wu, S.; Gong, G.; Wang, Y.; Li, F.; Jia, S.; Qin, F.; Ren, H.; Liu, Y. Response surface optimization of enzyme-assisted extraction polysaccharides from Dictyophora indusiata. Int. J. Biol. Macromol. 2013, 61, 63-68. [CrossRef]

42. Rajalakshmi, N.; Sundaram, P.V. Stability of native and covalently modified papain. Protein Eng. Des. Sel. 2015, 8, 1039-1047. [CrossRef] [PubMed]

43. Qin, Y.; Yuan, Q.; Zhang, Y.; Li, J.; Zhu, X.; Zhao, L.; Wen, J.; Liu, J.; Zhao, L.; Zhao, J. Enzyme-assisted extraction optimization, characterization and antioxidant activity of polysaccharides from sea cucumber Phyllophorus proteus. Molecules 2018, 23, 590. [CrossRef] [PubMed]

44. Wang, L.; Liu, F.; Li, T.; Liu, D.; Xu, Y.; Yang, Y. Enzyme assisted extraction, purification and structure analysis of the polysaccharides from naked pumpkin seeds. Appl. Sci. 2018, 8, 1866. [CrossRef]

45. Sharma, A.; Khare, S.K.; Gupta, M.N. Enzyme-assisted aqueous extraction of rice bran oil. J. Am. Oil Chem. Soc. 2001, 78, 949-951. [CrossRef]

46. Huang, Y.; Yin, Z.; Guo, J.; Wang, F.; Zhang, J. Oil extraction and evaluation from yellow horn using a microwave-assisted aqueous saline process. Molecules 2019, 24, 2598. [CrossRef] 
47. Sarker, M.Z.I.; Selamat, J.; Habib, A.S.M.; Ferdosh, S.; Akanda, M.J.H.; Jaffri, J.M. Optimization of supercritical $\mathrm{CO} 2$ extraction of fish oil from viscera of African catfish (Clarias gariepinus). Int. J. Mol. Sci. 2012, 13, 11312-11322. [CrossRef]

48. Kuo, C.-H.; Huang, C.-Y.; Chen, J.-W.; Wang, H.-M.D.; Shieh, C.-J. Concentration of docosahexaenoic and eicosapentaenoic acid from cobia liver oil by acetone fractionation of fatty acid salts. Appl. Biochem. Biotechnol. 2020, 192, 517-529. [CrossRef]

49. Kuo, C.-H.; Huang, C.-Y.; Lee, C.-L.; Kuo, W.-C.; Hsieh, S.-L.; Shieh, C.-J. Synthesis of DHA/EPA ethyl esters via lipase-catalyzed acidolysis using Novozym ${ }^{\circledR}$ 435: A kinetic study. Catalysts 2020, 10, 565. [CrossRef]

50. Xu, J.; Zhao, Q.; Qu, Y.; Ye, F. Antioxidant activity and anti-exercise-fatigue effect of highly denatured soybean meal hydrolysate prepared using neutrase. J. Food Sci. Technol. 2015, 52, 1982-1992. [CrossRef]

51. Rajapakse, N.; Mendis, E.; Jung, W.-K.; Je, J.-Y.; Kim, S.-K. Purification of a radical scavenging peptide from fermented mussel sauce and its antioxidant properties. Food Res. Int. 2005, 38, 175-182. [CrossRef]

52. Guo, H.; Kouzuma, Y.; Yonekura, M. Structures and properties of antioxidative peptides derived from royal jelly protein. Food Chem. 2009, 113, 238-245. [CrossRef]

53. Wattanasiritham, L.; Theerakulkait, C.; Wickramasekara, S.; Maier, C.S.; Stevens, J.F. Isolation and identification of antioxidant peptides from enzymatically hydrolyzed rice bran protein. Food Chem. 2016, 192, 156-162. [CrossRef] [PubMed]

54. Ren, J.; Zhao, M.; Shi, J.; Wang, J.; Jiang, Y.; Cui, C.; Kakuda, Y.; Xue, S.J. Purification and identification of antioxidant peptides from grass carp muscle hydrolysates by consecutive chromatography and electrospray ionization-mass spectrometry. Food Chem. 2008, 108, 727-736. [CrossRef] [PubMed]

55. Samaranayaka, A.G.; Li-Chan, E.C. Food-derived peptidic antioxidants: A review of their production, assessment, and potential applications. J. Funct. Foods 2011, 3, 229-254. [CrossRef]

56. You, L.; Zhao, M.; Regenstein, J.M.; Ren, J. Changes in the antioxidant activity of loach (Misgurnus anguillicaudatus) protein hydrolysates during a simulated gastrointestinal digestion. Food Chem. 2010, 120, 810-816. [CrossRef]

57. Wang, Y.; Wang, Z.; Cheng, S.; Han, F. Aqueous enzymatic extraction of oil and protein hydrolysates from peanut. Food Sci. Technol. Res. 2008, 14, 533. [CrossRef]

58. Hathwar, S.C.; Bijinu, B.; Rai, A.K.; Narayan, B. Simultaneous recovery of lipids and proteins by enzymatic hydrolysis of fish industry waste using different commercial proteases. Appl. Biochem. Biotechnol. 2011, 164, 115-124. [CrossRef]

59. Chi, C.-F.; Hu, F.-Y.; Wang, B.; Li, Z.-R.; Luo, H.-Y. Influence of amino acid compositions and peptide profiles on antioxidant capacities of two protein hydrolysates from skipjack tuna (Katsuwonus pelamis) dark muscle. Mar. Drugs 2015, 13, 2580-2601. [CrossRef]

60. Farvin, K.S.; Andersen, L.L.; Nielsen, H.H.; Jacobsen, C.; Jakobsen, G.; Johansson, I.; Jessen, F. Antioxidant activity of Cod (Gadus morhua) protein hydrolysates: In vitro assays and evaluation in $5 \%$ fish oil-in-water emulsion. Food Chem. 2014, 149, 326-334. [CrossRef]

61. Wu, H.-C.; Chen, H.-M.; Shiau, C.-Y. Free amino acids and peptides as related to antioxidant properties in protein hydrolysates of mackerel (Scomber austriasicus). Food Res. Int. 2003, 36, 949-957. [CrossRef]

62. Xiao, F.; Chen, S.; Li, L.; He, J.; Cheng, W.; Ren, G. In vitro antioxidant activity of peptides from simulated gastro-intestinal digestion products of Cyprinus carpio haematopterus scale gelatin. Foods 2019, 8, 618 . [CrossRef] [PubMed]

63. Minekus, M.; Alminger, M.; Alvito, P.; Ballance, S.; Bohn, T.; Bourlieu, C.; Carriere, F.; Boutrou, R.; Corredig, M.; Dupont, D. A standardised static in vitro digestion method suitable for food-an international consensus. Food Funct. 2014, 5, 1113-1124. [CrossRef] [PubMed]

64. Huang, C.-Y.; Kuo, C.-H.; Lee, C.-H. Antibacterial and antioxidant capacities and attenuation of lipid accumulation in 3T3-L1 adipocytes by low-molecular-weight fucoidans prepared from compressional-puffing-pretreated sargassum crassifolium. Mar. Drugs 2018, 16, 24. [CrossRef] [PubMed]

65. Yang, K.-R.; Yu, H.-C.; Huang, C.-Y.; Kuo, J.-M.; Chang, C.; Shieh, C.-J.; Kuo, C.-H. Bioprocessed Production of Resveratrol-Enriched Rice Wine: Simultaneous Rice Wine Fermentation, Extraction, and Transformation of Piceid to Resveratrol from Polygonum cuspidatum Roots. Foods 2019, 8, 258. [CrossRef] [PubMed] 
66. Gnanou, J.; Srinivas, S.; Kurpad, A. Automated derivatization with o-phthalaldehyde for the estimation of amino acids in plasma using reversed-phase high performance liquid chromatography. Indian J. Biochem. Biophys. 2004, 41, 322-325. [PubMed]

67. Sultana, H.; Onodera, R.; Or-Rashid, M.M.; Wadud, S. Convenient method for the determination of arginine and its related compounds in rumen fluid by reversed-phase high-performance liquid chromatography. J. Chromatogr. B Biomed. Sci. Appl. 2001, 755, 321-329. [CrossRef]

Publisher's Note: MDPI stays neutral with regard to jurisdictional claims in published maps and institutional affiliations.

(C) 2020 by the authors. Licensee MDPI, Basel, Switzerland. This article is an open access article distributed under the terms and conditions of the Creative Commons Attribution (CC BY) license (http://creativecommons.org/licenses/by/4.0/). 